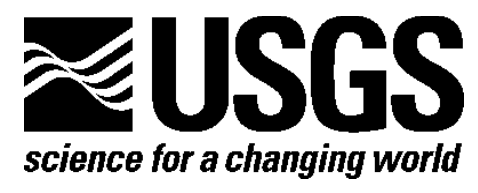

\title{
Thermal Maturity Data Used by the U.S. Geological Survey for the U.S. Gulf Coast Region Oil and Gas Assessment
}

By Kristin O. Dennen, Peter D. Warwick, and Elizabeth Chinn McDade

Open-File Report 2010-1072

Version 1.1

U.S. Department of the Interior

U.S. Geological Survey 


\section{U.S. Department of the Interior \\ KEN SALAZAR, Secretary}

\section{U.S. Geological Survey \\ Marcia K. McNutt, Director}

U.S. Geological Survey, Reston, Virginia: 2010

For product and ordering information:

World Wide Web: http://www.usgs.gov/pubprod

Telephone: 1-888-ASK-USGS

For more information on the USGS—-the Federal source for science about the Earth,

its natural and living resources, natural hazards, and the environment-

World Wide Web: http://www.usgs.gov

Telephone: 1-888-ASK-USGS

Suggested citation:

Dennen, K.O., Warwick, P.D., and McDade, E.C., 2010, Thermal maturity data used by the U.S. Geological Survey for the U.S. gulf coast region oil and gas assessment (ver. 1.1): U.S. Geological Survey Open-File Report 2010-1072, 7 p. plus one appendix, available at http://pubs.usgs.gov/ofr/2010/1072/.

Any use of trade, product, or firm names is for descriptive purposes only and does not imply endorsement by the U.S. Government.

Although this report is in the public domain, permission must be secured from the individual copyright owners to reproduce any copyrighted material contained within this report. 


\section{Contents}

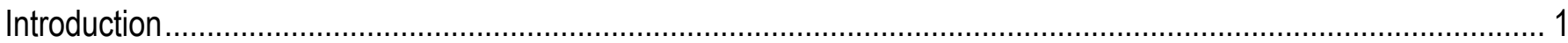

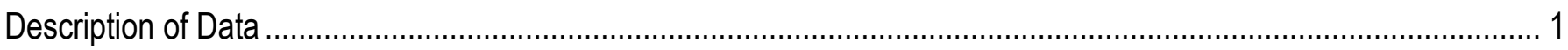

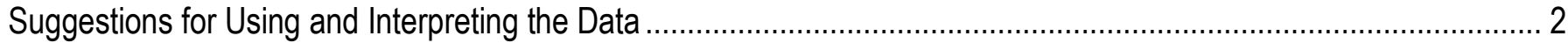

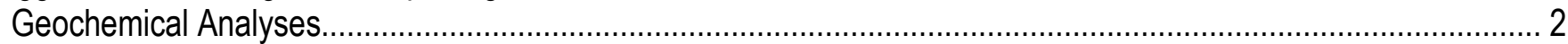

Latitudes, Longitudes, and Identification Information .............................................................................. 3

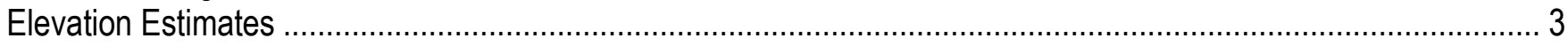

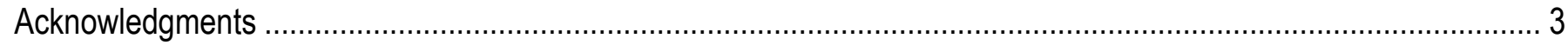

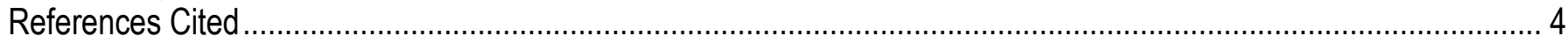

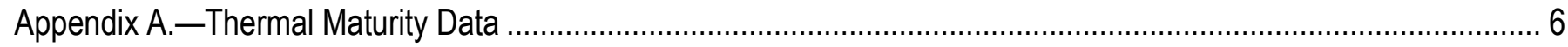

\section{Tables}

1. Thermal maturity data for core and cuttings samples from oil and gas wells-Descriptions............................ 1

2. Thermal maturity data for surface samples and coal core and mine samples-Descriptions .......................... 2

A-1. Thermal maturity data for core and cuttings samples from oil and gas wells.................................. [Excel file]

A-2. Thermal maturity data for surface samples and coal core and mine samples ................................. [Excel file]

\section{Conversion Factors}

\begin{tabular}{lcc}
\hline Multiply & By & To obtain \\
\hline & Length & \\
\hline foot $(\mathrm{ft})$ & 0.3048 & meter $(\mathrm{m})$ \\
\hline
\end{tabular}

Temperature in degrees Celsius $\left({ }^{\circ} \mathrm{C}\right)$ may be converted to degrees Fahrenheit ( $\left.{ }^{\circ} \mathrm{F}\right)$ as follows:

$$
{ }^{\circ} \mathrm{F}=\left(1.8 \times^{\circ} \mathrm{C}\right)+32
$$




\title{
Thermal Maturity Data Used by the U.S. Geological Survey for the U.S. Gulf Coast Region Oil and Gas Assessment
}

\author{
By Kristin O. Dennen, ${ }^{1}$ Peter Warwick, ${ }^{1}$ and Elizabeth Chinn McDade ${ }^{2}$
}

\section{Introduction}

The U.S. Geological Survey (USGS) is currently assessing the oil and natural gas resources of the U.S. Gulf of Mexico region using a total petroleum system (TPS) approach (Klett and others, 2000). An essential part of this geologically based method is evaluating the effectiveness of potential source rocks in the petroleum system. The purpose of this report is to make available to the public RockEval and vitrinite reflectance data from more than 1,900 samples of Mesozoic and Tertiary rock core and coal samples in the Gulf of Mexico area in a format that facilitates inclusion into a geographic information system (GIS). These data provide parameters by which the thermal maturity, type, and richness of potential sources of oil and gas in this region can be evaluated.

\section{Description of Data}

The data are divided into spreadsheets - data from oil and gas well cores and cuttings samples (table $A-1$ ) with American Petroleum Institute (API) numbers (American Petroleum Institute, 1979) and data from gulf coast surface samples and coal core and mine samples (table A-2). Sample analyses are accompanied by geospatial data (latitude, longitude, and sample elevation estimates) and geographical information (county and State). API numbers are supplied with oil and gas well data to facilitate use of gulf coast region online State oil and gas databases to access more information.

Variable headings for the oil and gas well sample and the surface sample and coal core and mine sample tables differ slightly because surface and coal samples do not have API numbers. Tables containing variable headings and explanations appear in tables 1 and 2.

\footnotetext{
${ }^{1}$ U.S. Geological Survey, Reston, Va.

${ }^{2}$ McMoRan Oil and Gas LLC, New Orleans, La.
} 
Table 1. Thermal maturity data for core and cuttings samples from oil and gas wells-Descriptions.

[Abbreviations used: API, American Petroleum Institute; $\mathrm{CO}_{2}$, carbon dioxide; $\mathrm{ft}$, foot]

Variable heading

API no.

Lease/well name

Field name

Remarks, longitude and latitude

Longitude

Latitude

Remarks, sample elevation estimates ( $\mathrm{ft}$ )

Sample elevation estimates

Group or formation

Group or formation age

State

County/parish

$\mathrm{T}_{\max }$

$\mathrm{S}_{1}$

$\mathrm{S}_{2}$

$\mathrm{S}_{3}$

PI

TOC

$\mathrm{HI}$

OI

Remarks TAI

TAI

Remarks \% $\mathrm{R}_{\mathrm{o}}$

$\% \mathrm{R}_{\mathrm{o}}$

Remarks, source of analyses

Source of analyses

Location source (if different from analytical source)
Description or explanation

A unique number that identifies a well site and cores taken from that well in public well records. It specifies the State, the county or parish, and in some States, a permit number for the well issued by the State in which the well is drilled.

Most wells are named for the person leasing or owning the land where the well is drilled. If multiple holes are drilled on a property, then the name is usually followed by a number.

Name of the oil or gas field in which the well is situated. This is usually specified in public well records. If the well is not associated with a particular field, then the well is usually called a "wildcat."

Arkansas township and range coordinates were converted to latitude and longitude using the University of Montana's conversion program available at http://www.esg.montana.edu/gl/trs-data.html.

Decimal degrees of longitude.

Decimal degrees of latitude.

If a sample is from an offshore well, this elevation includes the depth of the water above the well location and is indicated by the remark "subsea."

Subsurface core sample elevations were estimated by subtracting the core depth reported for the sample from the land surface elevation at the latitude and longitude of the core hole.

Geologic name of group or formation from which sample was taken.

Geologic name for the age of the group or formation from which sample was taken.

State where well is located and where there are related public records.

County or (in the case of Louisiana) parish in which the well is located. If the sample is from an offshore well in Federal waters, then there is no county or parish name associated with it.

Temperature from RockEval analysis corresponding to maximum $\mathrm{S}_{2}$ production in ${ }^{\circ} \mathrm{C}$.

Milligrams of free organic compounds per gram of sample.

Milligrams of hydrocarbons derived from kerogen, resins, and asphaltenes per gram of sample.

Milligrams of $\mathrm{CO}_{2}$ per gram of sample released between $300^{\circ}$ and $390^{\circ} \mathrm{C}$.

Production index $=\mathrm{S}_{1} / \mathrm{S}_{1}+\mathrm{S}_{2}$

Total organic carbon content of sample in weight percent.

Hydrogen index $=$ milligrams $\mathrm{S}_{2}$ per gram TOC $\times 100$.

Oxygen index $=$ milligrams $\mathrm{S}_{3}$ per gram TOC $\times 100$.

Range of visual reference scale used for TAI determination.

Thermal alteration index; determined using a visual reference scale.

If the $R_{o}$ values are calculated, then this is noted. The formula for calculating the value, if known, is provided.

Mean value of percent reflectance measurements of vitrinite in oil (American Society for Testing and Materials, 2007), unless otherwise noted.

In a single published report, different analytical laboratories providing analyses are indicated if given. If data are unpublished, then that and permission to publish the data are indicated.

Published reference from which the analyses were taken or laboratory that provided the analyses.

If the locations for the well core samples were not provided in the publication or by the analytical laboratory, then the locations were retrieved from a publically available online database of well locations. 
Table 2. Thermal maturity data for surface samples and coal core and mine samples-Descriptions.

[Abbreviations used: $\mathrm{CO}_{2}$, carbon dioxide; $\mathrm{ft}$, foot]

\begin{tabular}{|c|c|}
\hline Variable heading & Description or explanation \\
\hline Sample name & Name of sample provided in report from which the analyses were taken. \\
\hline Sample type, lithology & $\begin{array}{l}\text { Description of sample type given in publication or by collector of a sample; whether it is from a } \\
\text { surface sample (taken from an outcrop) or a well core or cuttings or taken from within a coal } \\
\text { mine. The analysis source should be consulted for a complete description. }\end{array}$ \\
\hline Location name & Name of mine or geographical name of area of outcrop from which coal sample was taken. \\
\hline Longitude & Decimal degrees of longitude. \\
\hline Latitude & Decimal degrees of latitude. \\
\hline $\begin{array}{l}\text { Sample elevation estimates } \\
\text { (ft) }\end{array}$ & $\begin{array}{l}\text { Subsurface core sample elevations were estimated by subtracting the core depth or coal seam } \\
\text { depth reported for the sample from the land surface elevation at the latitude and longitude at } \\
\text { the sample site. If a sample was taken at the surface, then this is the height of the outcrop } \\
\text { given by the collector or publication. }\end{array}$ \\
\hline Group or formation & Geologic name of group or formation from which sample was taken. \\
\hline Group or formation age & Geologic name for the age of the group or formation from which sample was taken. \\
\hline State & State where mine or surface sample was obtained. \\
\hline County/parish & County or (in the case of Louisiana) parish where the mine or surface sample was obtained. \\
\hline $\mathrm{T}_{\max }$ & Temperature from RockEval analysis corresponding to maximum $\mathrm{S}_{2}$ production in ${ }^{\circ} \mathrm{C}$. \\
\hline $\mathrm{S}_{1}$ & Milligrams of free organic compounds per gram of sample. \\
\hline $\mathrm{S}_{2}$ & Milligrams of hydrocarbons derived from kerogen, resins, and asphaltenes per gram of sample. \\
\hline $\mathrm{S}_{3}$ & Milligrams of $\mathrm{CO}_{2}$ per gram of sample released between $300^{\circ}$ and $390^{\circ} \mathrm{C}$. \\
\hline PI & Production index $=\mathrm{S}_{1} / \mathrm{S}_{1}+\mathrm{S}_{2-}$ \\
\hline TOC & Total organic carbon content of sample in weight percent. \\
\hline $\mathrm{HI}$ & Hydrogen index $=$ milligrams $\mathrm{S}_{2}$ per gram TOC $\times 100$. \\
\hline OI & Oxygen index $=$ milligrams $\mathrm{S}_{3}$ per gram TOC $\times 100$ \\
\hline$\% \mathrm{R}_{\mathrm{o}}$ & $\begin{array}{l}\text { Mean value of percent reflectance measurements of vitrinite in oil (American Society for Testing } \\
\text { and Materials, 2007), unless otherwise noted. }\end{array}$ \\
\hline $\begin{array}{l}\text { Remarks, source of } \\
\text { analyses }\end{array}$ & $\begin{array}{l}\text { If data are unpublished that is indicated. If special permission to publish the data was granted, that } \\
\text { is indicated. }\end{array}$ \\
\hline Source of analyses & Published reference from which the analyses were taken or laboratory that provided the analyses. \\
\hline $\begin{array}{l}\text { Location source (if } \\
\text { different from } \\
\text { analytical source) }\end{array}$ & $\begin{array}{l}\text { If the locations for the core samples were not provided in the publication or by the analytical } \\
\text { laboratory, then the locations were retrieved from a publically available online database of } \\
\text { well locations. The database source of the location data is indicated. }\end{array}$ \\
\hline
\end{tabular}

\section{Suggestions for Using and Interpreting the Data}

\section{Geochemical Analyses}

Each sample entry in the dataset contains a reference to the source of the data. Because the sample analyses come from a variety of sources, it is important to understand how the analytical values were derived and how they can be compared. The source for each group of data should be consulted to ascertain the analytical methods and reporting conventions used.

Definitions of the geochemical parameters used in source rock evaluation and descriptions of how source rock geochemical analyses are applied to petroleum exploration can be found in Peters and Casa (1994). The American Society for Testing and Materials (ASTM) (2007) methods D2797 and 
D2798 respectively contain detailed descriptions of how samples are prepared and analyzed for vitrinite reflectance measurements and how the measurements are reported.

Some of the major source rocks in the Gulf of Mexico, such as the Jurassic Smackover Formation, are marine carbonates. This creates a set of problems for thermal maturity interpretation from vitrinite reflectance data owing to the frequently very low concentrations of nonmarine, plantbased materials from which vitrinite reflectance measurements are made. Two references that address the problems of source rock thermal maturity evaluation in the Gulf of Mexico are Sassen and Moore (1988) and Jarvie and others (2001).

\section{Latitudes, Longitudes, and Identification Information}

Sometimes the sources of the data and of the geospatial information are different. The authors verified and updated the well identification and location information where possible, but there may be recent changes in the API numbers owing to the fact that the API well identification system is being updated to reflect constantly evolving drilling technology (IHS Energy Group, 2008). For the data from Arkansas, only township and range figures were available, so those data were converted using the online calculator at Montana State University's Website (http://www.esg.montana.edu/gl).

Wells drilled before the introduction of digital recordkeeping may not appear in online databases; therefore it may be necessary to contact the appropriate State recordkeeping agency directly for up-to-date information.

\section{Elevation Estimates}

Subsurface core sample elevations were estimated by subtracting the reported core depth from the land surface elevation at the latitude and longitude of the core hole. The accuracy of the estimated elevation estimations depends not only on the reported latitude and longitude but also on the source of data for the digital elevation model (DEM) used for the estimates. Because the land surface elevations in this report have been determined by several DEMs, it is best to consult the sources for each set of data if extremely accurate sample elevations are needed. The USGS National Elevation Dataset (NED) is the basis for many DEMs (U.S. Geological Survey, 2002, 2006).

\section{Acknowledgments}

The log and core facility of the Bureau of Economic Geology of the University of Texas at Austin provided samples of Tuscaloosa marine shale from Mississippi. Keith F.M. Thompson, Roger Sassen, and Norman Guissano, Jr., Director, Geochemical and Environmental Research Group, College of Geosciences, Texas A\&M University, were instrumental in the release of data associated with the Gulf of Mexico Petroleum Correlation Study (Thompson and Kennicutt, 1992). Crishun Brown of the Texas Railroad Commission provided assistance and copies of her research on locations of Texas wells that could not be located in the Texas Railroad Commission's online database. Paul Walker of Baseline Resolution Weatherford Laboratories and P.K. Mukhopadhyay gave permission to release the proprietary analyses in Dow and Mukhopadhyay (1988). Donald Goddard and John E. Johnston III at the Louisiana Geological Survey gave permission for publication of the analyses from Goddard (1995). Sigrid Clift of the Texas Bureau of Economic Geology gave permission for publication of the analyses in Mukhopadhyay (1989). Charles Barker (emeritus) of the USGS gave permission for some of his analyses to appear in this report. Mike Lewan of the USGS allowed the release of some of his recent analyses and made helpful suggestions for reference works on the use and interpretation of thermal maturity data. Jennie Ridgley (emeritus) of the USGS provided new unpublished analyses of her work on core and cuttings samples from Texas and Louisiana. Paul Hackley and Jamey McCord of the USGS 
provided analytical data and sample location information. Chris Garrity and Alex Karslen of the USGS advised on the uses of DEMs and provided GIS assistance.

Mark Pawlewicz and Elizabeth Rowan of the USGS reviewed this report. Their comments and suggestions improved it, and the authors greatly appreciate their assistance.

\section{References Cited}

American Petroleum Institute, 1979, The API well number and standard state and county numeric codes including offshore waters: Dallas, Tex., American Petroleum Institute Bulletin D12A, 136 p.

American Society for Testing and Materials, 2007, Gaseous fuels; Coal and coke, sec. 5 of Annual book of ASTM standards-Petroleum products, lubricants, and fossil fuels: West Conshohocken, Penn., American Society for Testing and Materials International, v. 5.06, 700 p.

Dow, W.G., and Mukhopadhyay, P.K., 1988, The Deep Wilcox from south-central Texas: The Woodlands, Tex., Baseline DGSI Analytical Laboratories Project 87/434, 39 p.

Goddard, D.A., 1995, Deltaic reservoir characterization, in Geological, petrophysical, and engineering applications: Baton Rouge, La., Louisiana Geological Survey Basin Research Institute Technical Report 95-2, $125 \mathrm{p}$.

Hackley, P.C., Hook, R.W., and Warwick, P.D., 2005, Huminite reflectance measurements of Paleocene and Upper Cretaceous coals from borehole cuttings, Zavala and Dimmit Counties, south Texas: U.S. Geological Survey Open-File Report 2005-1144, 13 p., accessed January 27, 2010, at http://pubs.usgs.gov/of/2005/1144/.

Hackley, P.C., Ratchford, M.E., and Warwick, P.D., 2006, Reflectance measurements of well cuttings from Ashley and Bradley Counties, Arkansas: U.S. Geological Survey Open-File Report 2006-1155, 29 p., accessed January 27, 2010, at http://pubs.usgs.gov/of/2006/1155/.

Hackley, P.C., and Warwick, P.D., 2005, Organic petrography of coals from a coalbed methane test well, Ouachita Parish, Louisiana: U.S. Geological Survey Open-File Report 2005-1134, 22 p., accessed January 27, 2010, at http://pubs.usgs.gov/of/2005/1134/.

Hackley, P.C., Warwick, P.D., Breland, F.C., Jr., Richard, T.E., and Ross, K., 2007, Results from coalbed methane drilling in Winn Parish, Louisiana: U.S. Geological Survey Open-File Report 20071061, 45 p., accessed January 27, 2010, at http://www.pubs.usgs.gov/of/2007/1061/.

IHS Energy Group, 2008, API new numbering guidelines: Englewood, Colo., IHS Energy Group, accessed January 27, 2010, at http://www.ihsenergy.com/support/reference_materials/apiguidelines/general_guides.jsp.

Jarvie, D.M., Morelos, A., and Han, Z., 2001, Detection of pay zones and pay quality, Gulf of MexicoApplication of geochemical techniques: Gulf Coast Association of Geological Societies Transactions, v. 51, p 151-160.

Klett, T.R., Schmoker, J.W., Charpentier, R.R., Ahlbrandt, T.S., and Ulmishek, G.F., 2000, Glossary, chap. GL of U.S. Geological Survey world petroleum assessment 2000-Description and results: U.S. Geological Digital Data Series 60, accessed January 27, 2010, at http://pubs.usgs.gov/dds/dds-060/.

Mancini, E.A., Aharon, P., Goddard, D.A., and Barnaby, R., 2006, Resource assessment of the in-place and potentially recoverable deep natural gas resource of the onshore interior salt basins, north central and northeastern Gulf of Mexico: U.S. Department of Energy Final Report DE-FC26-03NT41875, $179 \mathrm{p}$.

McDade, E.C., 1992, Organic-rich lower Tertiary shales, south Louisiana-Implications for petroleum source rock deposition: Baton Rouge, La., Louisiana State University Ph.D. dissertation, 255 p. 
Mukhopadhyay, P.K., 1989, Organic petrography and organic geochemistry of Texas Tertiary coals in relation to depositional environment and hydrocarbon generation: Bureau of Economic Geology, The University of Texas at Austin Report of Investigations 188, $118 \mathrm{p}$.

Penn Virginia Oil and Gas, 2005, Horizontal wells-A viable method for exploitation of coalbed methane from the Wilcox coals of the central gulf coast: Mississippi/Alabama Division of the U.S. Oil and Gas Association 2007 Oil and Gas Forum Annual Meeting, 63d, October 17-19, 2007, Point Clear, Ala., accessed January 27, 2010, at http://www.usoga.com/events/presentations/wilcox_lewis.pdf.

Peters, K.E., and Cassa, M.R., 1994, Applied source rock geochemistry, in Magoon, L.B., and Dow, W.G., eds., The petroleum system-From source to trap: Tulsa, Okla., American Association of Petroleum Geologists Memoir 60, p. 93-120.

Price, L.C., 1982, Organic geochemistry of core samples from an ultradeep hot well $\left(300^{\circ} \mathrm{C}, 7 \mathrm{~km}\right)$ : Chemical Geology, v. 37, no.3-4, p. 215-228.

Price, L.C., 1989, Louisiana oil-oil correlation by iso-cyclic, aromatic, and gasoline-range hydrocarbons, with an appendix of organic-geochemical rock data from selected wells in the gulf coast: U.S. Geological Survey Open-File Report 89-358, 90 p., accessed January 28, 2010, at http://pubs.er.usgs.gov/djvu/OFR/1989/ofr_89_358.djvu.

Price, L.C., and Clayton, J.L., 1990, Reasons for and significance of deep high-rank hydrocarbon generation in the south Texas gulf coast, in Gulf Coast Section Society for Sedimentary Geology Annual Research Conference, 9th, Proceedings: Tulsa, Okla., Society for Sedimentary Geology, p. $105-137$.

Sassen, Roger, and Moore, C.H., 1988, Framework of hydrocarbon generation and destruction in eastern Smackover trend: American Association of Petroleum Geologists Bulletin, v. 72, no. 6, p. 649-663.

Thompson, K.F.M., and Kennicutt, M.C., II, 1992, Correlations of gulf coast petroleums on the basis of branched acyclic alkanes: Organic Geochemistry, v. 18, no. 1, p. 103-119.

U.S. Geological Survey, 2002, The national map-Elevation: U.S. Geological Survey Fact Sheet 10602, accessed January 27, 2010, at http://egsc.usgs.gov/isb/pubs/factsheets/fs 10602.html.

U.S. Geological Survey, 2006, National elevation dataset: U.S. Geological Survey, accessed January 27 , 2010, at http://ned.usgs.gov/.

Wagner, B.E., Sofer, Z., and Claxton, B.L., 1994, Source rock in the Lower Tertiary and Cretaceous deep-water Gulf of Mexico: Transactions of the Gulf Coast Association of Geological Societies, v. 44, p. 729-736.

Warwick, P.D., Breland, F.C., Jr., Hackley, P.C., Dulong, F.T., Nichols, D.J., Karlsen, A.W., Bustin, R.M., Barker, C.E., Willett, J.C., and Trippi, M.H., 2006, Analytical results from samples collected during coal-bed methane exploration drilling in Caldwell Parish, Louisiana: U.S. Geological Survey Open-File Report 2006-1213, 520 p., accessed January 28, 2010, at http://pubs.usgs.gov/of/2006/1213/.

Warwick, P.D., SanFilipo, J.R., Karlsen, A.W., and Barker, C.E., 2005, Results of coalbed methane drilling in Panola County, Texas: U.S. Geological Survey Open-File Report 2005-1046, 155 p., accessed January 28, 2010, at http://pubs.usgs.gov/of/2005/1046/. 


\section{Appendix A.-Thermal Maturity Data}

Table A-1. Thermal maturity data for core and cuttings samples from oil and gas wells.

Table A-2. Thermal maturity data for surface samples and coal core and mine samples. 